\title{
Unschooling Alternative : Studi Analisis Alternatif Pendidikan Menurut Pemikiran Everett Reimer
}

\author{
Tasurun Amma ${ }^{1 *}$ \\ ${ }^{1}$ Sekolah Tinggi Ekonomi Dan Bisnis Islam Darussalam (STEBIS) OKI SUMSEL \\ *E-mail: tasurun@gmail.com
}

\begin{abstract}
Abstrak
Penelitian ini bertujuan untuk mendapatkan kejelasan yang mendalam terkait pandangan Everett Reimer terhadap lembaga sekolah dan pandangannya tentang konsep penyelenggaraan pendidikan selain sekolah.Dari hasil penelitian terungkap bahwa pemikiran Everett Reimer bukan berarti anjuran eliminasi atas sekolah, akan tetapi Reimer menghendaki penghilangan kemapanan sekolah atau dengan kata lain posisi superior sekolah dilemahkan. Hal ini dikarenakan sekolah merupakan lembaga yang memiliki banyak sekali kelemahankelemahan sehingga mengalami kematian fungsinya sebagai lembaga pendidikan. Selanjutnya Reimer menyarankan untuk melakukan pengembangan atas kegiatan belajar yang lebih demokratis dan efisien dalam membelajarkan manusia, Reimer menawarkan sistem penyelenggaraan unschooling alternative yang terdiri dari empat macam bentuk yang saling berkaitan yakni pertama mengupayakan penyediaan jaringan benda, kedua penyediaan jaringan orang, ketiga penyediaan layanan yang memungkinkan seseorang menemukan partner belajar berupa jaringan teman sebaya yang cocok, dan keempat penyediaan layanan jaringan menuju para pendidik.
\end{abstract}

Kata Kunci: Everett Reimer, Unschooling Alternative, Sekolah

\section{PENDAHULUAN}

Pendidikan yaitu segala proses kehidupan manusia itu sendiri. Karena dalam proses kehidupan, selama fungsi-fungsi indra dan pikiran masih berjalan, di situlah terjadi transmisi pengetahuan, sikap, kepercayaan, keterampilan dalam porsinya masing-masing. Hal ini sangat sejalan dengan apa yang diungkapkan oleh Redja Mudyarahardjo (2001 : 45), menurutnya pendidikan adalah kesuluruhan pengalaman belajar setiap orang sepanjang hidupnya. Namun pendidikan oleh para pakar juga dimaknai secara terbatas pada sebuah kegiatan yang sengaja diupayakan untuk mencapai tujuan tertentu.Seperti Marimba yang mengartikan pendidikan sebagai bimbingan secara sadar oleh pendidik terhadap perkembangan jasmani dan rohani anak didik menuju terbentuknya kepribadian yang utama. Pengertian tersebut mendekati pendidikan yang disebut sekolah.

Semua orang tentu tahu bahwa masa belajar di sekolah selalu dibatasi waktu. Rata-rata anak bersekolah mulai pagi hingga siang menjelang sore dan selebihnya ia habiskan di luar lingkungan itu seperti bersama keluarga, masyarakat, teman bermain dan sebagainya. Dilihat dari jenjang persekolahanpun, pendidikan di sekolah itu -terutama di Indonesia- sangat terbatas pada waktu 12 tahun untuk merampungkan pendidikan dasar dan menengah. Dan bisa bertambah kurang lebih 8 tahun jika dilanjut ke pendidikan tinggi. Dengan demikian waktu yang dihabiskan manusia itu sebenarnya lebih banyak di luar sekolah dari pada di dalam sekolah. Dan sudah barang tentu waktu yang paling lama dialami itu akan semakin dominan mempengaruhi perkembangan manusia. Selain fakta tersebut, kita tahu bahwa sekolah adalah sebuah lembaga yang memiliki daftar panjang permasalahan yang itu sangat kontradiktif dengan keberadaannya sebagai lembaga pendidikan.Permasalahan-permasalahan di sekolah tersebut diantaranya dapat disaksikan dalam 
pemberitaan di media massa, para ahli dan praktisi hukum justru menjadi pelanggar hukum hingga muncul sebutan mafia hukum, aparat keamanan justru menciptakan suasana tidak aman, pendidik merusak citra pendidikan, korupsi dilingkungan pemerintah tidak terkendali, pergaulan bebas mengakar.

Hal-hal diatas merupakan sederet masalah secara umum yang ada dalam sebuah lembaga pendidikan yang dinamakan sekolah, banyak pihak yang mempertanyakan jika sekolah masih diagung-agungkan sebagai satu-satunya lembaga yang menjadi media untuk mengembangkan potensi manusia. Diantara para kritikus dan pakar pendidikan yang dengan giat melakukan koreksi terhadap lembaga pendidikan -utamanya persekolahan- adalah Everertt Reimer, dia menyusun buku yang berjudul school is dead yang merupakan pembicaraan dengan ivan illich yang berlangsung selama 15 tahun. Reimer bertemu dengan illich di puerto rico saat itu dia menjabat sebagai sekertaris panitia sumber-sumber tenaga kerja manusia pemerintahan persemakmuran, bertindak sebagai konsultan tenaga kerja dan rekomendator suatu program pendidikan, sedangkan illich menunaikan tugas suci untuk mengorganisasi program pelatihan untuk para pastur (Everett Reimer, $1987: 1$ ).

Sedikit membahas tentang Arthur Everett Reimer. Remier adalah Tokoh intelektual yang dikenal sebagai filosof, Birokrat, Ekonom, pendidik, maupun kritikus sosial. la dilahirkan pada tanggal 23 mei 1910. ayah dan lbunya diketahui keluarga dari keturunan berkebangsaan inggris. Semenjak kecil Reimer dikenal dengan anak yang cerdas dan kritis hingga masa dewasanya dilalui dengan gemilang dibuktikan dengan beberapa prestasi yang diukir oleh dia, diantaranya mempertahankan karir yang panjang sebagai birokrat profesional, peneliti, ahli perencanaan ekonomi, sosial dan pendidikan nasional. Hingga pada tahun 1949 sebagai ahli dibidang birokrasi dia menulis buku yang berjudul Translation of Research Findings into Administrative Action (Everett Reimer, 1949) hasil penelitiannya itu diterbitkan di kota Washington D.C.

Everett Reimer termasuk seorang yang sangat produktif dalam menghasilkan karya tulis. Dan memang melalui tulisan itulah dia bersuara., menyebarkan ide-ide dan kritik kontroversialnya. Karya tulis Reimer ada yang telah dipublikasikan secara resmi melalui penerbitan, majalah ataupun jurnal, ada juga yang tidak diterbitkan, namun hanya tersimpan sebagai arsip ketika dia aktif di lembaga CIDOC. Diantara karya-karyanya yang ditulis adalah sebagai berikut:

Everett Reimer, Translation of Research Findings into Administrative Action (Washington D.C: mimeographed paper presented at ASPL, 1949)

Everett Reimer, Social Planning: Collected Papers 1957-1968. (Cuernavaca: CIDOC, 1968)

Everett Reimer, Proposal for a Planning Seminar Aimed at the Development of Basic Educational Alternatives (Cuernavaca: CIDOC, 1968)

Everett Reimer "Second Annual Report of the Seminar on Alternatives in Education." (Cuernavaca: CIDOC, 1969) CIDOC Documents 69/167, September 1969. 23 pp.

Everett Reimer, La Educacion Descarriada I,II(Cuernavaca: CIDOC, 1969).

Pandangan Reimer tentang lembaga sekolah, sebagaimana dikutip Azyumardi Azra, mengatakan bahwa, sekolah bagi kebanyakan orang adalah institusi pendukung hak-hak istimewa (privilese), bahkan pada waktu yang sama merupakan instrumen bagi mobilitas vertikal masyarakat. Sistem kelembagaan pendidikan semacam sekolah membuat tidak semua masyarakat bisa menikmati akses pendidikan. Kalaupun mampu, mereka akan drop-out. Sebab biaya pendidikan dimana-mana semakin meningkat dengan cepat melebihi peningkatan pendapatan nasional. Maka, menurut Reimer, untuk meratakan pendidikan, lembaga-lembaga seperti sekolah harus dilenyapkan karena telah mengalami kematian fungsi (Azyumardi Azra, $2008: 16$ ).

Melihat beberapa paparan argumentasi diatas, penulis menduga bahwa Everertt Reimer bermaksud untuk menghilangkan dominasi sekolah sebagai penyelenggara pendidikan dan menganjurkan pengembangan bentuk-bentuk pendidikan yang lebih sesuai dan mendukung perkembangan manusia yang sedang menjalani proses belajar. Jika memang demikian, maka hal ini tentu merupakan sebuah modal untuk membangun konsep penyelenggaraan pendidikan yang lebih humanis dan berkepentingan pada pengembangan potensi-potensi manusia seutuhnya. 


\section{METODE/EKSPERIMEN}

Penelitian ini menggunakan pendekatan kualitatif yang dilakukan dengan melakukan penelitian kepustakaan (Library Research), dimana data-data diperoleh melalui tela'ah atas karya-karya tulis Everett Reimer dan sumber-sumber data lain yang relevan. Proses telaah itu dimulai dengan mengumpulkan karya-karya yang relevan, mendokumentasikannya serta melakukan analisis untuk memperoleh pemahaman yang utuh dan komprehensif. Sedangkan metode analisis yang digunakan dalam penelitian ini adalah content analisys, induksi, deduksi, komparasi serta interpretasi.

\section{HASIL DAN PEMBAHASAN}

\section{Unschooling dan paham Anarkisme}

Anarkisme dalam ruang lingkup pemikiran sosial modern diidentifikasi sebagai sebuah pemikiran yang menolak aturan-aturan dan bahkan dalam ruang lingkup yang lebih luas ia menolak keberadaan negara. Pendapat mereka yang populer adalah bahwa tatanan sosial mungkin terwujud jika tidak ada negara dan terdapat dukungan kepada gerakan ke arah masyarakat tanpa negara". (William Outhwaite, 2008 : 16). Tokoh-tokoh seperti Godwin, Wolff, Stirner juga melakukan penguatan terhadap hal yang sama. Sebagaimana dikutip Outhwaite bahwa seorang anarkis "mengharuskan individu bertindak berdasarkan penilaian mereka". Stirner juga mengatakan bahwa individu yang unik adalah yang benar-benar memiliki dirinya sendiri; dan tidak mengakui kewajiban kepada orang lain. Dan dalam batas-batas kekuasaannya, seseorang melakukan apa-apa yang benar bagi dirinya. Dalam pemikiran anarkisme filosofis juga dikatakan bahwa kerjasama dan keberadaan organisasi formal sebagai sesuatu yang bermasalah. Maka dari itu dalam setiapkesempatan mereka selalu mencurigai otoritas. Pemikiran Everett Reimer dalam hal ini seperti apa yang telah dikatakan Wiliam D'Oneil masuk pada wilayah ideologi Anarkisme.

Sedangkan William D'Oniel dari perspektif ideologi pendidikan, memandang bahwa anarkisme dalam pembahasan ideologi pendidikan adalah sudut pandang dalam dunia pendidikan yang membela pemusnahan kekanganlembaga terhadap kebebasan manusia sebagai suatu jalan untuk mewujudkan berkembangnya potensi manusia dengan sepenuhnya (William F.O'Neil, 2002 : 482).

Seorang anarkis memandang bahwa sebuah lembaga merupakan perampas kebebasan manusia melalui proses pemerosotan kedudukan individu menjadi sekedar fungsi dari kelompok. Dalam arti ketika seorang individu melakukan proses kerjasama dengan orang lain melalui sebuah lembaga sebagai konsekuensi sebagai makhluk sosial ia akan mudah terbantu dalam pemenuhan hidupnya. Tetapi kenyataannya di masyarakat ketika seorang individu telah menyatu dengan lembaga, ia menjadi teridentifikasi dengan lembaga dan proses-proses politik yang lambat laun memerosotkan perannya sebagai individu yang bebas. Kewenangan-kewenangan personal yang dimilikinya sedikit demi sedikit hilang oleh proses sosialisasi dan peraturan-peraturan yang menuntut untuk ditaati. Akhirnya ia menjadi individu yang pasif, reaktif dan makin kurang sosial.

Jika pemahaman ini ditarik ke fenomena lembaga sekolah dalam rangkaian pemikiran Reimer, memang bisa jadi terdapat relevansi dan itu juga bisa menjadi pembenaran dari pendapat William dan Outhwaite di atas. Semenjak menjadi Birokrat dan puncaknya pada saat di CIDOC, ia begitu concern mengkritik lembaga sekolah yang semakin kehilangan fungsinya. Setelah itu ia mengarahkan kritiknya pada lembaga-lembaga lain yang memiliki kararteristik sama dengan sekolah. Semua lembaga itu tadi menurut reimer telah menjadikan manusia mengalami ketergantungan dalam tahap yang tidak wajar. Sehinggamenurut Reimer semua jenis lembaga yang mengalami kematian fungsinya harus segera dilemahkan kemapanannya.

\section{Unschooling dan Birokrat}

Sebelum menjadi seorang kritikus pendidikan, Reimer adalah seorang birokrat profesional, ia 
mengawali karirnya sebagai sebagai sekretaris panitia sumber tenaga kerja manusia persemakmuran, yang bertugas untuk menetapkan apa yang diperlukan oleh tenaga kerja pulau itu dan merekomendasikan suatu program pendidikan, dan disinilah Reimer mulai meragukan sistem sekolah yang mulanya dianggap sebagai lembaga yang efektif dan demokratis yang mampu mewadahi masyarakat teknologi yang semakin efisien dan mampu menampung seluruh anak untuk mengenyam pendidikan, tetapi ternyata setelah meneliti kenyataan lapangan, angka putus sekolah semakin naik sedangkan negara belum mampu untuk menyediakan sekolah bagi semua anak.

Penelitian Reimer terkait pendidikan sekolah berlanjut pada saat ia menggabungkan diri dengan Alliance of Progress di Amerika Latin ini, Reimer termotivasi untuk mendalami permasalahan mengenai tingkah laku institusional sekolah, dan akhirnya ia mendapatkan kesimpulan bahwa masalah pendidikan yang terdapat disini sama dengan yang ada di puerto Rico, tetapi lingkupnya jauh lebih luas.

Hal ini memaksa Reimer untuk mengadakan analisis secara mendalam terkait sistem sekolah yang semakin kehilangan fungsinya sebagai lembaga pendidikan yang seharusnya bisa dinikmati oleh seluruh orang tetapi malah cenderung mempertahankan posisi hak-hak istimewa (privileged), oleh karenanya Reimer berusaha untuk mengkritisi habis-habisan terhadap lembaga sekolah dan mencoba untuk memberikan model-model alternatif pendidikan selain sekolah yang membebaskan peserta didik, tidak membelenggunya dengan klasifikasi usia yang ada di dalamnya, pembagianpembagian kelas, pengukuranpengukuran kemampuan manusia melalui sistem evaluasi, kurikulumkurikulum yang dipaksakan kepada siswa, serta dengan selembar ijazah yang dianggap menggambarkan capaian-capaian dalam proses pendidikan sekolah, yang pada akhirnya itu ditukar dengan sebuah pos atau jabatan dalam suatu perusahaan.

Konsekuensi dari kedalaman analisisnya untuk memberikan kontribusi positif terhadap pendidikan, akhirnya tampak pada setiap analisisnya dalam buku school is dead,yang pada intinya Reimer tidak sepakat dengan adanya lembaga sekolah, karena telah mengalami kematian fungsi sehingga keberadaan sekolah harus segera dilakukan pelucutan atas kemapanannya.

Unschooling alternative : Antara kelebihan, kekurangan dan kaitannya dengan pendidikan di Indonesia

Jika melakukan flash back sejenak ke belakang, tepatnya pada era dimana gagasan unschoolingitu muncul, yakni pada dekade 1960-an, maka setidaknya pemikiran Reimer akan bisa dipahami secara utuh dengan mempertimbangkan konteksnya. Ini tetap menjadi penting agar seandainya pemikiran ini diadopsi sebagai sebuah solusi, maka terdapat landasan yang kokoh tentang sebab-sebab lahirnyasuatu pemikiran.

Dilihat dari sisi historis, pemikiran Reimer tentang sekolah ini lahir dalam sebuah tempat dan keadaan yang cukup kompleks. Dari beberapa literature, setidaknya terdapat beberapa keterangan bahwa Reimer bertempat tinggal berpindah-pindah dari satu wilayah ke wilayah yang lain. Selama dekade 1960-an, ia aktif di kota Poerto Rico, untuk menjalankan tugasnya sebagai sekretaris panitia sumber tenaga kerja manusia persemakmuran. Kota-kota di Amerika Serikat seperti Washington saat bergabung dengan alliance of progress, serta di Cuenarva, Meksiko sebagai direktur lembaga CIDOC.

Dari hal ini dapat diketahui bahwa Reimer berinteraksi dengan realitasrealitas yang ada di benua amerika, baik itu di Amerika Serikat, Meksiko, Puerto Rico maupun di Negara kawannya Paulo Freire, Brazil. Realitas-realitas yang ada di masing-masing negara tentu berbeda. Di Amerika Serikat Reimer menyaksikan bagaimana Program Pendidikan bernilai milyaran dolar dikucurkan untuk sekolahan. Namun semua itu hanya bisa dinikmati secara maksimal oleh orang-orang berkulit putih. Orang-orang dengan kulit berwarna tidak mendapatkan manfaat dari kucuran dana yang begitu besar secara maksimal. Sedangkan di negara lain seperti negara-negara Amerika Latin yang tertinggal, Reimer menyaksikan betapa kemiskinan telah dimodernisasi sedemikian rupa dengan keberadaan lembaga sekolah. Di banyak negara Amerika Latin misalnya terdapat semacam definisi kemiskinan dengan menyebut bahwa yang dikatakan orang miskin adalah mereka dengan tingkat pendidikan 
yang lebih rendah.Program-program mahal seperti Alliance for Progress yang galakkan Presiden Kennedy dalam kenyataannya justru juga tidak secara maksimal mampu mendongkrak pendidikan di negara tertinggal seperti negara-negara di Amerika Latin. Makawajarlah, dari sisi ekonomi Reimer begitu menyayangkan hal itu. Bagi Reimerlebih baik dana itu digunakan untuk membangun jaringan belajar yang lebih murah dan dapat menjangkau siapa saja.

Allen J. Moor (1984 : 110) mengatakan bahwa konsep Reimer yang dirumuskan dalam konteks Amerika Latin tidak bisa begitu saja diterapkan dal;am konteks yang berbeda, karena situasi dan kondidinya tidak sama. Jika hal ini ditarik dalam konteks pendidikan di Indonesia, maka perlu ada beberapa pertimbangan dengan melihat kenyataan yang ada dalam pendidikan di Indonesia yang hampir seluruhnya diselenggarakan oleh sekolah. Peringatan Moor ini adalah suatu kendali supaya kita tidak bertindak naif dalam suatu masalah yang tidak sesuai dengan konteksnya, hal itu juga menjadi peringatan supaya kritikan Reimer dapat dipakai dalam menganalisis permasalahan bendidikan diseluruh belahan dunia termasuk di indonesia..

Pendidikan dilndonesia juga menjadikan sekolah sebagai tonggak utama dalam mengemban amanah undang-undang untuk mencerdaskan bangsa.Indonesia -dalam undang-undang pendidikannya- juga membedakan pendidikan dalam tiga bentuk yakni pendidikan formal melalui sekolah-sekolah, pendidikan non formal seperti pondok pesantren dan madrasah diniyah, serta pendidikan informal yang dilaksanakan secara mandiri oleh keluarga. Pembedaan itu tentu tidak kecil dampaknya terhadap perhatian pemerintah terhadap pendidikan. Pembedaan itu juga menghasilkan anggapan yang berkembang luas di masyarakat bahwa hanya pendidikan formal yang layak untuk mendidik anak anak. Sedangkan pendidikan dalam bentuk lain kurang diperhatikan.

Dalam hal anggaran pendidikan, pembedaan itu sangat jelas. Anggaran pendidikan lebih banyak diberikan kepada pendidikan formal seperti sekolah, perguruan tinggi. Bahkan itupun hanya banyak terserap ke lembaga-lembaga yang berada dalam tanggungan pemerintah (berstatus negeri). Sekolah dan lembaga-lembaga swasta tetap saja secara mandiri membiayai pendidikan. Padahal jika dilihat kenyataannya bahwa sekolah sering memiliki permasalahan-permasalahan seperti kekerasan, korupsi dana pendidikan, ketidakjujuran, rasanya sangat tidak proporsional jika fokus anggaran hanya tertuju kepada lembaga sekolah.

Maka dalam konteks ini, tawaran-tawaran Everett Reimer dalam rangkaian kritiknya terhadap sekolah dan bentuk kegiatan penyelenggaraan pendidikan tanpa sekolah, perlu dipertimbangkan untuk diadopsi. Pertimbanganpertimbangan itu perlu diawali dengan melakukan penilaian terhadap pemikiran Unschooling-nya, serta menimbang kemungkinan-kemungkinan penerapan jaringan belajar sebagaimana yang ditulis Reimer dalam buku dan artikel-artikelnya.

Dalam paparan di bab-bab yang awal telah di jelaskan bahwa Everett Reimer mengkritik penyelenggaraan sekolah yang penuh dengan kebobrokan. Everett Reimer dengan baik menjelaskan tiap detil keburukan sekolah. Sekolah baginya adalah institusi pencetak mitos-mitos atau keyakinankeyakinan kosong di tengah-tengah masyarakat. Sekolah juga merupakan institusi yang secara kelembagaan memungkinkan seorang guru melakukan diskriminasi dan perlakuan tidak baik kepada murid-muridnya. Sistem di sekolah yang terdiri dari guru, murid, kurikulum, waktu belajar dan kewajiban-kewajiban hadir di kelas telah menyebabkan terhambatnya proses belajar yang sesungguhnya. Atas dasar itu ia mengajukan altematif solusi berupa jaringan-jaringan yang memungkinkan seseorang untuk melakukan belajar sesuai keinginannya dan terhindar dari hal-hal buruk yang biasa dilakukan oleh lembaga sekolah.

Dari paparan-paparan yang terdahulu tentang gagasan Everett Reimer, terlihat bahwa Reimer begitu piawai dalam mengoreksi keburukan lembaga sekolah. Itu bisa dilihat dari bukunya yang hampir secara keseluruhan berisi kritikan terhadap sekolah. Dari lima belas bab yang disajikan, sembilan bab berisi kritikan terhadap sekolah, dua bab berisi alternatif pendidikan, danempat pandangan filosofik tentang kearifan manusia.. Dari kenyataan itu terlihat bahwa Reimer memang menonjol dalam mengkritik sekolah. Tapi, ia kurang begitu komprehensif dalam menawarkan solusi. Maka wajarlah banyak yang menyangsikan pemikiran Everett Reimerini. 
Seperti halnya wacana Reimer untuk mengenyahkan kurikulum, Seperti halnya pakar-pakar pendidikan aliran kiri lain, Reimer menganggap kurikulum sebagai bentuk pengetahuan mati”, peserta didik tak diperkenankan memperdalam apa yang menjadi minatnya, kurikulum bak momok yang memenjarakan kapasitas intelektual. Upaya Reimer guna melegitimasi argumennya dilakukan dengan memetik kata-kata salah satu jenius yang pernah dimiliki dunia yakni Einstein, ia pernah berkata bahwa apa yang menghambatnya dalam studi adalah sekolah itu sendiri, lanjut Einstein, ia juga mengatakan kehilangan minat berbagai pekerjaan kreatif akibat waktunya yang tersita untuk menyiapkan berbagai ujian sekolah.Bagi Reimer pembebasan kurikulum bakal berdampak positif bagi orang-orang seperti Einstein, tetapi yang menjadi permasalahan kemudian, tidak setiap siswaterutama mahasiswa-memiliki pola pikir yang sama seperti Einstein-katakanlah sebagai mahasiswa yang memiliki kemapanan berpikir. Efisiensi dan efektivitas guna membina mahasiswa-mahasiswa berbakat seperti Einstein hendaknya dilakukan dengan menyediakan sekolah-sekolah khusus berikut dengan berbagai ketentuan kualifikasi peserta didik tentunya.

Apa yang menjadi cita-cita Reimer untuk "mengenyahkan" kurikulum sekolah kian sulit diwujudkan saat ini. Hal ini cukup jelas tampak dalam kehidupan sehari-hari kita di mana para pelajar, terutama pada tingkatan SMA dan perguruan tinggi larut dalam budaya hedonis siang dan malam, berlomba-lomba melakukan konsumsi hasil kontruksi pabrik-pabrik bergengsi, tenggelam dalam gaya hidup, budaya ini tak hanya berlangsung di tahun-tahun terakhir ini, bahkan telah berlangsung sejak 1970-an (M. Achmad Icksan, 1985 : 35). apa yang menjadi pijakan saya dalam hal ini salah satunya adalah kesaksian Hawking di mana pada 1970-an ia menuntut ilmu di Cambridge dan menemui bahwa mahasiswa-mahsiswa yang benar-benar serius dalam belajar-jumlahnya sangat minoritashanya menjadi bahan olok-olok teman-temannya. Kebanyakan mahasiswa dunia kala itu larut dalam kehidupan kampus yang glamor, foya-foya, tiada malam tanpa pesta dan sayangnya budaya tersebut masih berlanjut hingga kini.

Melihat berbagai realitas di atas, cukuplah akal sehat kita mengakui bahwa kurikulum kian absurd untuk ditiadakan saat ini. Jika kita mengkaji lebih dalam lagi, pemaknaan sekolah pada awalawal berdirinya yakni di era Yunani Kuno atau jauh sebelum itu, dalam upacara-upacara manusia primitif memang memandang budaya-budaya hedonis di atas tidak ada salahnya sama sekali karena memang sekolah berasal dari kata scholay yang berarti waktu luang, jadi pada pakem awalnya sekolah adalah tempat untuk mengisi waktu luang (Save Robinson, 2002 : 65). Namun, perkembangan zaman melalui kemajuan teknologi dan pembangunan-pembangunan dinamisnya menggugurkan itu semua, sekolah kemudian tak dapat sekedar menjadi tempat pengisian waktu luang atau sambilan semata, konstelasi Eropa abad pertengahan, Kekhalifahan Islam dan dengan berjalannya waktu hingga saat ini menjadikannya sebagai suatu institusi yang mutlak dan wajib eksistensinya bagi kemakmuran dan ketahanan suatu bangsa dan negara.

Problem lainnya adalah pendidikan di Indonesia memang belum memiliki relevansi yang sangat kuat dengan program pendidikan sebagaimana didesain oleh para praktisi pendidikan pembebasan. Dalam banyak hal, pendidikan Indonesia masih didesain sebagai model pendidikan yang lebih menekankan pada dimensi pengetahuan atau knowledge. Akan tetapi, yang masih tampak mengedepan adalah penerapan pembelajaran yang menekankan pada aspek pengetahuan teoretik atau konseptual daripada praktis. Sehingga dimensi praktis harus dibahas dan dilaksanankan dalam sekolah agar pendidikan dapat menjadikan outputnya memiliki seperangkat keterampilan praksis.

Melihat pernyataan itu, maka sebenarnya segala bentuk belajar apapun selalu memiliki potensi buruk bagi proses pendidikan. Sistem jaringan sebagaimana yang ditawarkan Everett Reimer dengan menyediakan jaringan benda, orang, teman sebaya dan pendidik, berupaya untuk meyakinkan seseorang bahwa hanya dengan itulah seseorang bisa belajar dengan haik, hanya dengan sistem jaringanversi Evertt Reimer proses pembelajaran akan berlangsung secara sempurna sebagaimana yang diharapkan. Setelah itu maka ia kemudian akan berubah menjadi superior dalam bentuknya yang lain, sehingga memaksa seseorang untuk belajar dengan cara itu. Dan yang terjadi selanjutnya adalah sebagaimana apa yang terjadi dalam lembaga sekolah yang dikritik Everett Reimer. Maka 
dengan demikian baik sekolah maupun Network Sistem memiliki potensi baik maupun buruk yang sama.

Maka sebenarnya yang terpenting adalah perlunya membangun kesadaran individu untuk belajar secara benar. Jika seseorang telah memiliki kesadaran itu, maka ketika itu ia akan mampu memilih cara belajar yang paling tepat untuk dirinya sendiri. Dengan kesadaran diri seseorang akan termotivasi secara pribadi untuk menemukan sumber-sumber belajar secara tepat. Bahkan iatidak akan merasa terdiskriminasi walaupun ia diajar dan diberikan pengetahuan oleh orang lain.

Maka dalam konteks ke-Indonesiaan, utamanya dalam pendidikan di Indonesia, hal yang terpenting adalah bagaimana unsur fundamental dari kesadaran manusia itu dibangun. Yang perlu diupayakan agar tercipta proses belajar yang humanis, jauh dari diskrimasi, dan efektif dalam mencapai tujuan belajar adalah membangun kesadaran. Upaya-upaya untuk membangun hal itu salah satunya bisa diwujudkan dengan alfabetisasi, yakni pemberantasan buta huruf sebagaimana yang ditawarkan oleh tokoh-tokoh semacam Everett Reimer. Jika buta huruf telah diberantas, dan dengan itu dia akan terbuka cakrawala pemikirannya dengan membaca, maka dengan sendirinya orang akan mampu untuk menemukan kesadaran dalam hal apapun. Seseorang akan mampu membangun sejarahnya sendiri secara kreatif.

\section{Kritikan Reimer terhadap sekolah}

Sebagai seseorang yang terlahir dalam keadaan yang penuh dengan sisi-sisi intelektualitas dengan hadirnya tokoh-tokoh intelektual, problem-problem sosial dan pendidikan menjadikan Everett Reimer dikenal sebagai seorang kritikus yang dengan keras mengkritik sekolah. Dalam pandangan Everett Reimer, sekolah perlu untuk dijadikan tidak mapan. Dalam arti superioritas sekolah sebagai lembaga pendidikan harus segeradihilangkan. Hal ini karena Everett Reimer memandang bahwa sekolah memiliki banyak kelemahan yang tidak sejalan dengan makna pendidikan itu sendiri.

Pemikiran dan kritik Everett Reimer dalam school is dead-nya dinilai mengandung kelemahan. Walaupun secara detail Everett Reimer mengajukan kritik terhadap sekolah, namun solusi yang ditawarkannya belum sampai pada tataran praktis dalam arti masih berkutat dalam dunia ide dan hanya dapat diterima sebagai penjelasan tentang teori dan pemikiran pendidikan..

2. Alternatif Tanpa Sekolah

Bagi Reimer kegiatan belajar selain sekolah dalam bentuk yang lebih baik perlu dicetuskan. Kegiatan belajar itu oleh Everett Reimer diwujudkan dalam gagasan yang merupakan tawaransolusinya, yaituberupa Jaringan-jaringan yang berupaya untuk menjadikan pendidikan sesuai dengan maknanya, jaringan tersebut adalah :

a. Jaringan Benda(Network of Things).

Barang-barang atau benda-benda merupakan bagian yangpenting dari sumber belajar dalam proses belajar manusia. Keberadaan material seperti buku-buku, komputer, alat peraga yang digunakan dalam laboratorium merupakan hal yang penting dalam mendukung terciptanya proses belajar. Interaksi manusia dengan benda-benda atau barang-barang tersebut akan sangat memungkinkan terwujudnya perubahan perilaku pada diri. Jikalau dalamsistem sekolah terdapat pembatasan terhadap akses menuju objek-objek belajar atau pendidikan, maka Reimer justru menggagas hal yang sebaliknya. Akses terhadap sumber-sumber belajar berupa benda-benda maupun barang-barang ini diperlebar sedemikian rupa sehingga bisa diakses oleh publik(umum).

b. Jaringan Orang(Network of People)

Kemampuan teknis yang perlu diupayakan untuk mengembangkan potensi manusia, tentu membutuhkan model atau dengan kata lain membutuhkan inspirasi dari orang lain tentang suatu keilmuan dasar. Langkah teknisnya digambarkan oleh Reimer dengan membuat daftar orang yang memiliki keterampilan dan bersedia menjadi model untuk orang lain dalam mempelajari keterampilan tersebut. Juga mencatat waktu luang yang mereka bersedia membagi pengetahuan tentang 
keterampilannya sekaligus alamat mereka yang bisa dikunjungi. Sehingga dari daftar ini, seorang siswa hanya tinggal melihat mereka ingin belajar keterampilan apa, kepada siapa mereka harus belajar, kapan dan dimana mereka akan melakukan pertukaran keterampilan itu.

c. Jaringan Teman Sebaya (Network of Peer)

Konsep teman sebaya (Peer Matching) disini juga berbeda denganGuru keterampilan, teman sebaya merupakan teman dengan kemampuan dan minat yang sama juga memiliki kapasitas intelektual yang setara. jaringan komunikasi teman sebaya yang memungkinkan orang memaparkan kegiatan belajar yang ingin mereka ikuti, dengan harapan menemukan pasangan yang cocok untuk kegiatan belajar mereka

d. JaringanPendidik (Network of Educators)

Pendidikyang dimaksud adalah pendidik yang menjalin persahabatan moral yang tidak pernah dibatasi waktu dan juga tempat, pendidik yang mengajar berdasarkan cinta kasih dan penuh rasa belas kasihan. Dengan keberadaan pendidik yang semacam ini, individu akan terbebaskan dari kewajiban menggantungkan diri pada guru-guru yang bekerja sebagai pelayan jasa professional.

\section{UCAPAN TERIMAKASIH}

Peneliti mengucapkan terimakasih kepada Sekolah Tinggi Ekonomi Dan Bisnis Islam Darussalam Lempuing OKI, LPPM STKIP Nurul Huda Sukaraja OKU Timur Dan Tim Jurnal AI I'tibar Program Studi Pendidikan Agama Islam STKIP Nurul Huda.

\section{DAFTAR PUSTAKA}

Arikunto, Suharsimi., 2006. Prosedur Penelitian. Jakarta : Rineka Cipta.

Azra, Azyumardi., 1998. Esei-esei Intelektual Muslim dan Pendidikan Islam,Jakarta : Logos Wacanallmu.

Bayu, Dardias., 2001. Praktek Penelitian Kualitatif: Pengalaman dari UGM. Yogyakarta: fisipol-UGM. Cayley, David., 1922. Ivan Illich In Conversation Concord, Ontario: House of Anansi Press Limited.

Creswell, John W., 2009. Research Design Qualitative, Quantitative, And Mixed Method Approaches. India: Sage Publication.

Darity Jr. William A., 2008. International Encyclopedia of the Social Sciences, USA : The Gale Group.

Eskobar, M., 1998. et. al. Sekolah Kapitalisme yang Licik: Dialog Bareng Paulo Freire, Terj: Muhdi Rahayu. Yogyakarta: LkiS.

F.O'Neil, William., 2002. Ideologi-ideologi l'endidlkan, terj. Omi Intan Naomi Yogyakarta:Pustaka Pelajar.

Fatimatuszahro', Paradigma Kritis Transformatif, http:// zeqwhomes .blogspot. com/2012/11/ paradigma-kritis-transformatif.html. Diakses tanggal 24 juni 2014

Hasan, Iqbal., 2004. Analisis Data Penelitian Dengan Statistik Jakarta : Bumi Aksara.

http://id.wikipedia.org/wiki/Margaret_Mead diakses tanggal 10 april 2015

Icksan, M. Achmad., 1985. Mahasiswa dan Kebebasan Akdemik, Yogyakarta: Hanindita.

Lemmerer, Elisabeth., 2008. " Examining a Sample of the American-Mexican Scientific Cooperation in the 1960s: A Social Network Analysis of the CIDOC-Network" thesis, Universitas Wien.

Margono, S., Metodologi 1997. Penelitian Pendidikan. Jakarta : Rineka Cipta.

Marimba, Ahmad., 1989. Pengantar Filsafat Pendidikan Islam. Bandung : Al-Ma'rif.

Moore,AllenJ.,1984. ContemporaryApproachestoChristianEducation. Nashville:AbingdonPress.

Reimer, Everert., 1971. Freing Educational Resources. Cuenarva: CIDOC.

1987. Sekitar Eksistensi Sekolah, Terj: Soedomo, Yogyakarta: Hanindinata Graha Widya.

1971. School is dead.: An essay on alternatives in education, Harmondsworth: Penguin.

Robinson, Dave., 2002. Nietzsche dan Posmodernisme. Yogyakarta: Jendela.

Soejono \& Abdurrahman., 1999. Metode Penelitian suatu Pemikiran dan Penerapan. Jakarta:Rineka Cipta.

William Outhwaite (Ed), 2008. Kamus Lengkap Pemikiran Sosial Modern. Jakarta:Kencana. 